\title{
Application of Point-of-Care Testing (POCT) in Diagnostics of Influenza during COVID-19 Pandemic in elderly Hospitalized People (Short Communication)
}
A. Liptakova (Adriana Liptakova) 1 , M. Dubinova (Martina Dubinova)'1 M. Straka (Marek Straka) $^{1}$, J. Predny (Jan Predny) 1 , A. Longauerova (Andrea Longauerova) ${ }^{1}$, A. Krajcikova (Adriana Krajcikova)' ${ }^{1}$, A. Koscalova (Alena Koscalova)², K. Vlckova $\left(\right.$ Katarina Vlckova) ${ }^{3}$, M. Novotny (Martin Novotny) ${ }^{4}$, P. Jarcuska (Pavol Jarcuska) ${ }^{4}$

${ }^{1}$ Department of Microbiology Medical Faculty Commenius University, Original Article Bratislava, Slovakia.

${ }^{2}$ Department of Infectology and Geographic Medicine Medical Faculty Commenius University, Bratislava, Slovakia.

${ }^{3}$ I. Internal Medicine Department, Medical Faculty Commenius University, Bratislava, Slovakia.

${ }^{4}$ Department of Infectology and Geographic Medicine Medical Faculty P.J. Safarik University Kosice, Slovakia.

\section{E-mail address:}

adriana.liptakova@fmed.uniba.sk

\section{Reprint address:}

Adriana Liptakova

Department of Microbiology, Faculty of Medicine,

Comenius University and University Hospital,

Bratislava

Slovakia

Source: Clinical Social Work and Health Intervention Pages: $56-62$

\section{Reviewers:}

Andrea A Shahum

Chapel Hill NC, USA

Claus Muss

IGAP Zurich $\mathrm{CH}$

\section{Publisher:}

International Society of Applied Preventive Medicine i-gap

\section{Keywords:}

Influenza A/B. POCT. Epidemiological Management. Antiviral Treatment.

CSWHI 2021; 12(1): 56 - 62; DOI: 10.22359/cswhi_12_1_12 (C) Clinical Social Work and Health Intervention

\section{Abstract:}

Influenza is a viral disease of the respiratory tract which affects a relatively large number of people in Slovakia and around the world every year. The patient groups most at risk are the elderly 
and immunocompromised patients in whom the disease can have serious outcomes including death. Therefore, early diagnosis of influenza and subsequent epidemiological management is very important. Point-of-care testing (POCT) seems to be very useful for rapid molecular diagnosis of influenza A and B viruses in patient samples. In today's coronavirus

\section{Editors Note:}

What Happened to Flu Season? on Feb, 25, 2021, Brenda Goodman, MA - WEBMD HEALTH NEWS reported that the U.S. is seeing historically low levels of influenza this season, which started in September 2020. This time last year, the national map of flu activity published by the CDC showed so many active cases that some states had or „very high" activity. This year, Public health labs across the U.S. reported a grand total of 3 cases of flu in the U.S. last week, out of nearly 16,000 samples tested. Clinical laboratories, which tested nearly 25,000 samples, found just 14 flu cases. So far this 2021 season, labs reporting to the CDC had just 1,585 samples test positive for flu of any kind. Compare that to last year over the same period, when there were more than 183,000 positive samples.. Vanderbilt University in Nashville is part of a network of hospitals that are actively looking for flu cases among their patients. They can't find any. This year, only one child has died of the flu. Last year, that number was 195.Why? People are taking precautions for COVID, including masking, social distancing, and frequent hand-washing. More people have taken CDC public health advice to get a flu vaccine. There is just much less human mobility \& travel this year. Children have been out of school $\&$ at home played less with other children.

\section{Introduction}

Influenza is a viral disease of the respiratory tract which affects a relatively large number of people in Slovakia and around the world every year $(1,2,3)$. 164, 883 cases of influenza in Europe have been reported to the WHO since the beginning of 2020 , with influenza A being confirmed in $73 \%$ and influenza B virus in $27 \%$ of cases (4). In the Slovak Republic, 1,470,688 acute respiratory diseases were recorded in the 2018-2019 season, which represents a morbidity of 55,104.9 per 100000 persons in the care of reporting physicians. The highest incidence was re- corded in the 19-59-year-old age group. In the 2017-2018 season, 632 samples in total were positive, with influenza A virus confirmed in 567 cases $(89.7 \%)$ and influenza B virus in 65 samples $(10.3 \%)$ (1). In the 2018-2019 season, out of 1,155 samples tested, the influenza A virus was confirmed in 296 cases $(98.9 \%)$ and the influenza $\mathrm{B}$ virus in 3 cases (1.1\%) (5). Those most at risk are the elderly and debilitated patients, in whom the disease can lead to death. Therefore, early diagnosis of influenza and subsequent epidemiological management is very important $(1,6)$.

\section{Pathogenesis of the disease and its clinical forms}

The source of the influenza infection are humans and some animals. As with SARS-CoV-2, the virus is transmitted by aerosol and large droplets (e.g. by sneezing) $(7,8)$. The target organ of influenza virus replication in humans is respiratory tract and the site of virus entry is its mucosa. The incubation period is 18 to 72 hours. The virus begins to spread from the infected individual to the environment 1 day before the onset of the first symptoms and the affected individual is infectious for 5 to 7 days. Initially, the virus causes a local infection of the upper respiratory tract and is found in large amounts in nasopharyngeal secretions. If it spreads to the lower respiratory tract, the infection can cause severe shedding of the bronchial or alveolar epithelium and induce inflammation. Influenza virus infection compromises the mucociliary clearance of the respiratory tract, which promotes the adhesion of bacteria to epithelial cells and the development of bacterial superinfection. Lung tissue damage can lead to hyaline membrane formation, alveolar emphysema, and alveolar wall necrosis. The cellular, interferon, and cytokine response in otherwise healthy individuals is usually sufficient to control the infection and is responsible for the development of systemic symptoms of influenza. 
Clinical manifestations of influenza appear suddenly. At the beginning, general symptoms prevail, especially fever, chills, headache, extremity or back muscle pain, nausea and loss of appetite. Severe eye muscle pain and watery and burning eyes can also appear. The overall discomfort lasts on average 3 days, as does the fever. Respiratory problems such as dry cough, inflammation, sore throat and runny nose appear at the onset of the disease. Unlike other upper respiratory tract infections, the most common manifestations of influenza are the general symptoms. In some cases, gastrointestinal symptoms can also appear (7). Similar symptoms are seen in patients infected with the new coronavirus SARS-CoV-2 causing COVID-19 (8). In young, otherwise healthy people, clinical manifestations of the infection can be of varying intensity, from asymptomatic or mild disease to cases with typical influenza symptoms. Complete recovery usually takes 1 to 2 weeks. Severe symptoms and worse course of the disease is observed in high-risk populations - children under 6 months of age, elderly, pregnant women, individuals with chronic respiratory disease, a weakened immune system or on immuno-suppressive treatment. The course of the disease caused by influenza B virus is usually milder compared to influenza A virus $(7,10)$.

\section{Treatment}

In most cases of uncomplicated influenza, symptomatic treatment (bed rest, hydration, vitamin supplementation and antipyretics) is sufficient. Antiviral medications are usually given to patients admitted to hospital, patients with severe or progressive disease course, children younger than 2 years, older persons ( $>65$ years), pregnant women and women up to 2 weeks postpartum. Currently, the most widely used antiviral medications are the neuraminidase inhibitors - oseltamivir and zanamivir. Zanamivir is administered by oral inhalation and oseltamivir is for oral use. Other promising antiviral medications inhibiting viral polymerase, endonuclease, and HA-mediated membrane fusion are under development $(7,11,12)$.

\section{Diagnostics}

Laboratory diagnosis of influenza during acute phase of the disease is based on direct detection of the virus after its isolation in tissue cul- tures or chicken embryos, or on detection of the viral antigen in the samples from the respiratory tract, or in some cases on a significant increase in specific antiviral antibodies. Nasopharyngeal swab or lavage must be performed within 72 hours after the disease onset, as the amount of virus present decreases rapidly thereafter. The result of virus isolation in tissue cultures may be available within 2 to 6 days. However, these methods are not part of routine microbiological diagnostics. Rapid immunochromatographic assays for antigen detection have relatively low sensitivity and specificity. Indirect diagnostic methods can help determine the diagnosis only during recovery phase based on a comparison of the titer of antibodies in paired serum samples taken several days or up to 2 weeks apart.

Currently, the real-time polymerase chain reaction (real-time PCR) is considered to be the most reliable laboratory diagnostic method for influenza A and B viruses $(7,13,14)$. Point-ofcare testing (POCT) appears to be very useful for rapid molecular detection of influenza $\mathrm{A}$ and $\mathrm{B}$ viruses in patient samples. These tests have a high analytical sensitivity and specificity in comparison with other methods used in diagnostic virology (viral culture, direct detection of antigen in swab samples, serology testing), and the samples can be tested immediately after collection (15). The early diagnosis of influenza enables quick isolation of infected individuals and early initiation of antiviral treatment in patients with complications and prevents the influenza spread and overprescription of antibiotics.

\section{Materials and methods}

The patients were diagnosed from October 2019 to May 2020, that means during the usual flu season and during the COVID-19 pandemic. Nasopharyngeal swabs were collected as clinical material from 89 patients with suspected influenza. POCT testing was ordered in patients with symptoms of acute respiratory disease and performed during patient examination in the emergency room of the 1st Department of Internal Medicine at the University Hospital Bratislava and in the emergency room of the Department of Infectology and Travel Medicine, Faculty of Medicine, Pavel Jozef Šafárik University, at Louis Pasteur University Hospital (UNLP) in Košice. Most patients were elderly. 
The collected samples were placed in a universal transport medium and immediately analyzed (no transport or storage). Detection of the influenza virus in the samples was performed using the $\operatorname{cobas}^{\circledR}$ Influenza A/B Assay on a cobas ${ }^{\circledR}$ Liat ${ }^{\circledR}$ System (Roche Molecular Systems, Pleasanton, California, USA). The assay uses multiplex real-time RT-PCR for detection. The viral RNA is reversely transcribed into complementary DNA, amplified, and its quantity is subsequently evaluated using fluorescent signals. The instrument is fully automated and the test takes only a few minutes. The results are available in approximately 20 minutes. The assay is not intended for serial testing (15).

\section{Results}

At the University Hospital Bratislava, the influenza A virus was detected in $9(13 \%)$ patients, and the influenza B virus in $7(10 \%)$ patients. The remaining $53(77 \%)$ patients were negative. Most persons tested were male - $42(61 \%)$. Of these, 11 were positive ( 6 had influenza A, 5 influenza B). Of the 27 (39\%) women tested, 5 were positive (3 had influenza A, 2 influenza B). The average age of patients diagnosed with influenza $A$ or $\mathrm{B}$ was 60 years. After clinical evaluation, 6 patients with the confirmed disease were transferred to the Department of Infectology and Geographical Medicine, Faculty of Medicine, SZU and UNB, where they were isolated and where 5 of these patients received antiviral treatment (Oseltamivir, Tamiflu ${ }^{\circledR}$ ) (tab. 1).

At UNLP in Košice, 20 patients were tested, and influenza was confirmed in 3 patients (15\%), influenza A in two men (10\%) (78 and 48 years old) and influenza B in 1 woman (31 years old). The results were also confirmed in the National Reference Center (NRC) for influenza. Samples from 10 patients were sent to the NRC for influenza and in all cases, the results were in concordance with our findings - 7 negative and 3 positive results (influenza A was confirmed in 2 cases and influenza B in 1 case). In three cases, the samples could not be analyzed, but in 1 case, the patient sample was transported in other than recommended transport medium. The proportion of diagnosed and confirmed patients from both sites is shown in Figure 2.
Figure 2: Proportion of influenza positive cases in patients with suspected influenza from UN Bratislava and UNLP Košice (influenza A 13\%, influenza B 10\%, negative $77 \%$, samples cannot be tested 3\%).

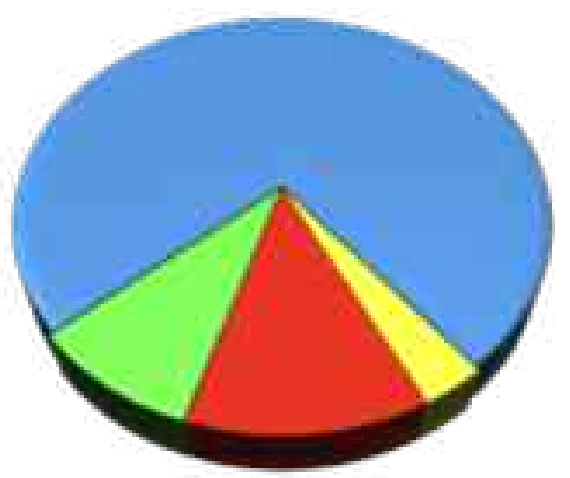

Influenza A Influenza B Negative

Samples cannot be tested

\section{Discussion and conclusions}

Influenza is a viral respiratory disease with the highest prevalence during the winter and spring months (8). Rapid POCT molecular tests appear to be appropriate for its early diagnosis and subsequent proper clinical and epidemiological management. They can distinguish influenza A from influenza B virus and their results are available within 20 minutes after sample collection, which represents a very significant progress in clinical virological diagnostics (15). POCT testing is ideal for patient triage during an epidemic and allows to initiate appropriate treatment almost immediately after patient's admission, and/or to implement preventive anti-epidemic measures immediately after the patient's initial examination. If the influenza virus is detected in the collected sample material by POCT, the same nasal and/or nasopharyngeal swab sample can be sent for virus isolation to NRC for influenza as a part of comprehensive diagnostics recommended by the WHO in its current strategy (16).

Although the group of our patients was relatively small ( 89 patients) and testing was also affected by the onset of the COVID-19 pandemic, the results are interesting - up to $22 \%$ of the ana- 
Table 1: Characteristics of hospitalized patients with confirmed influenza A or B

\begin{tabular}{|c|c|c|c|c|}
\hline $\begin{array}{l}\text { Patient } \\
\text { gender } \\
\text { and age }\end{array}$ & Comorbidities & $\begin{array}{l}\text { Administered } \\
\text { medications }\end{array}$ & Outcome & $\begin{array}{l}\text { Length of } \\
\text { hospitalization }\end{array}$ \\
\hline $\begin{array}{l}\text { Male, } \\
40 \text { years } \\
\text { old }\end{array}$ & $\begin{array}{l}\text { Influenza ABacterial } \\
\text { tracheobronchitisSevere } \\
\text { bronchial asthma }\end{array}$ & $\begin{array}{l}\text { Oseltamivir }\left(\text { Tamiflu }^{\circledR}\right) \\
\text { Ceftriaxone }\end{array}$ & $\begin{array}{l}\text { Discharged } \\
\text { from the hospi- } \\
\text { tal to home } \\
\text { care in a good } \\
\text { health condi- } \\
\text { tion }\end{array}$ & 4 days \\
\hline $\begin{array}{l}\text { Female, } \\
86 \text { years } \\
\text { old }\end{array}$ & $\begin{array}{l}\text { Influenza A with hypox- } \\
\text { emic-hypercapnic respira- } \\
\text { tory failure Sepsis caused } \\
\text { by Staphylococcus aureus } \\
\text { secondary pneumonia } \\
\text { Acute cystitis caused by } \\
\text { Escherichia coliPersistent } \\
\text { atrial fibrillation with } \\
\text { rapid ventricular respon- } \\
\text { seChronic ischemic heart } \\
\text { disease, unspecifiedAcute } \\
\text { decompensated chronic } \\
\text { left ventricular heart fail- } \\
\text { ure }\end{array}$ & $\begin{array}{l}\text { Oseltamivir }\left(\text { Tamiflu }^{\circledR}\right) \\
\text { Ceftriaxone } \\
\text { LinezolidClarithromy- } \\
\text { cinO }_{2}\end{array}$ & \begin{tabular}{|l|} 
Cardiology re- \\
ferral to the 5th \\
Department of \\
Internal \\
Medicine, Fac- \\
ulty of \\
Medicine, UK \\
and UNB in \\
Bratislava Ruži- \\
nov
\end{tabular} & 13 days \\
\hline $\begin{array}{l}\text { Male, } 40 \\
\text { years old }\end{array}$ & $\begin{array}{l}\text { Influenza AMild hypona- } \\
\text { tremiaDehydrationArte- } \\
\text { rial hypertension }\end{array}$ & $\begin{array}{l}\text { Oseltamivir } \\
\left(\text { Tamiflu }^{\circledR}\right)\end{array}$ & \begin{tabular}{|l|} 
Discharged \\
from the hospi- \\
tal to home \\
care in a good \\
health condi- \\
tion
\end{tabular} & 11 days \\
\hline $\begin{array}{l}\text { Female, } \\
85 \text { years } \\
\text { old }\end{array}$ & $\begin{array}{l}\text { Influenza AArterial hyper- } \\
\text { tension grade } 2 \\
\text { (ESC/ESH) with very high } \\
\text { CV risklschemic heart dis- } \\
\text { ease with angina pectoris } \\
\text { and heart failure }\end{array}$ & ClarithromycinO $_{2}$ & $\begin{array}{l}\text { Discharged } \\
\text { from the hospi- } \\
\text { tal to home } \\
\text { care in an im- } \\
\text { proved health } \\
\text { condition }\end{array}$ & 5 days \\
\hline $\begin{array}{l}\text { Male, } 64 \\
\text { years old }\end{array}$ & $\begin{array}{l}\text { Influenza B Bilateral } \\
\text { bronchopneumonia pre- } \\
\text { dominantly involving the } \\
\text { lung bases COPDArterial } \\
\text { hypertension grade } 2 \\
\text { (ESH/ESC) with high CV } \\
\text { risk }\end{array}$ & $\begin{array}{l}\text { Oseltamivir }\left(\text { Tamiflu }^{\circledR}\right) \\
\text { CeftriaxoneO }_{2}\end{array}$ & \begin{tabular}{|l|} 
Discharged \\
from the hospi- \\
tal to home \\
care in an im- \\
proved health \\
condition
\end{tabular} & 7 days \\
\hline
\end{tabular}




\begin{tabular}{|c|c|c|c|c|}
\hline $\begin{array}{l}\text { Male, } 58 \\
\text { years old }\end{array}$ & $\begin{array}{l}\text { Influenza A } \\
\text { Bronchopneumonia } \\
\text { involving the right lung } \\
\text { New onset paroxysmal } \\
\text { atrial fibrillation with } \\
\text { normal ventricular } \\
\text { response, CHA2DS2- } \\
\text { VASc score 3, HAS-BLED } \\
\text { score } 1 \\
\text { Chronic left ventricular } \\
\text { heart failure with re- } \\
\text { duced ejection fraction } \\
\text { (37\%) }\end{array}$ & $\begin{array}{l}\text { Oseltamivir } \\
\text { (Tamiflu }^{\circledR} \text { ) } \\
\text { Ceftriaxone } \\
\mathrm{O}_{2}\end{array}$ & $\begin{array}{l}\text { Discharged } \\
\text { from the hospi- } \\
\text { tal to home } \\
\text { care in an im- } \\
\text { proved health } \\
\text { condition }\end{array}$ & 6 days \\
\hline $\begin{array}{l}\text { Male, } 79 \\
\text { years old }\end{array}$ & $\begin{array}{l}\text { Influenza A } \\
\text { Bilateral interstitial } \\
\text { pneumonia } \\
\text { Arterial hypertension } \\
\text { grade } 2 \text { (ESH/ESC) with } \\
\text { high CV risk } \\
\text { Type } 2 \text { diabetes }\end{array}$ & $\begin{array}{l}\text { Oseltamivir } \\
\left(\text { Tamiflu}^{\circledR}\right) \\
\text { Cefotaxime } \\
\text { Clarithromycin } \\
\mathrm{O}_{2}\end{array}$ & $\begin{array}{l}\text { Discharged } \\
\text { from the De- } \\
\text { partment of } \\
\text { Pneumology } \\
\text { UNLP to home } \\
\text { care in an im- } \\
\text { proved health } \\
\text { condition }\end{array}$ & 7 days \\
\hline $\begin{array}{l}\text { Male, } 48 \\
\text { years old }\end{array}$ & $\begin{array}{l}\text { Influenza A } \\
\text { Obesity } \\
\text { Arterial hypertension } \\
\text { grade } 1 \text { (ESH/ESC) with } \\
\text { high CV risk, treated by } \\
\text { beta-blockers }\end{array}$ & $\begin{array}{l}\text { Oseltamivir } \\
\left(\text { Tamiflu }^{\circledR}\right) \\
\text { Clarithromycin } \\
\mathrm{O}_{2}\end{array}$ & $\begin{array}{l}\text { Discharged } \\
\text { from the hospi- } \\
\text { tal to home } \\
\text { care in an im- } \\
\text { proved health } \\
\text { condition }\end{array}$ & 7 days \\
\hline $\begin{array}{l}\text { Female, } \\
31 \text { years } \\
\text { old }\end{array}$ & $\begin{array}{l}\text { Influenza B } \\
\text { No comorbidities } \\
\text { Returned from China }\end{array}$ & $\begin{array}{l}\text { Oseltamivir } \\
\left(\text { Tamiflu }^{\circledR}\right)\end{array}$ & $\begin{array}{l}\text { Discharged } \\
\text { from the hospi- } \\
\text { tal to home } \\
\text { care in a good } \\
\text { health condi- } \\
\text { tion }\end{array}$ & 3 days \\
\hline
\end{tabular}

lyzed samples (19 in total) were positive. The high ratio of detected influenza $B$ virus strains to influenza A strains (8 to 11) was also interesting. In contrast, in the 2018-2019 season, the ratio of influenza B cases to influenza A cases in the group of samples tested by Regional Public Health Authorities in the Slovak Republic was 3 to 296 (5).

Influenza A or B was confirmed in 16 patients of the group examined at the 1st Department of Internal Medicine LF UK and UNB. Thanks to the rapid POCT diagnostics, it was possible to prevent the spread of influenza in the medical facilities, the health of other patients was not put at risk, and the patients could receive antiviral medications.

The introduction of POCT testing for influenza A and B at both sites was clearly a great benefit in the diagnosis of acute respiratory diseases and was also relatively simple, fast, and reliable thanks to the chosen testing platform. The introduction of rapid diagnostics for influenza and in the future possibly for SARS-CoV-2 at the hospital emergency departments will signifi- 
cantly improve the triage of patients with symptoms of respiratory infection and minimize the risk of hospital-acquired infections.*

*Conflict of interests: The authors have no conflict of interests.

\section{References}

1. THE SLOVAK NATIONAL PUBLIC HEALTH AUTHORITY (2019) Evaluation of annual influenza season and vaccination rate 2018/2019. https://www.cdc.gov/flu/about/k eyfacts.htm. https://www.who.int/en/newsroom/fact-sheets/detail/influenza-(seasonal). https://www.ecdc.europa.eu/en/publicationsdata/influenza-virus-characterisation-summary- europe-june-2020

2. THE SLOVAK NATIONAL PUBLIC HEALTH AUTHORITY (2020) Annual evaluation of National Reference Centres in 2019.

3. TAUBENBERGER J K, MORENS D M (2006) 1918 Influenza: the mother of all pandemics. Emerging Infectious Diseases,: 1522.

4. LIPTAKOVAA. et al. (2019) Medical Microbiology. Bratislava: Herba s. r. o.

5. LIPTAKOVA A., DUBINOVA M (2020) Coronoaviruses - should we be afraid of? Medical Horizon, 69 (3): 70-72.

6. MURRAY P R, ROSENTHAL K S, PFALLER M A (2013) Medical Microbiology. 7th ed. Elsevier Saunders, http://www.cdc.gov/ swineflu/index.htm. http://www.cdc.gov/ swineflu/recommendations.htm.

7. UYEKI T M, BERNSTEIN H H, BRADLEY J S, et al. (2019) Clinical Practice Guidelines by the Infectious Diseases Society of America: 2018 Update on Diagnosis, Treatment, Chemoprophylaxis, and Institutional Outbreak Management of Seasonal Influenza. Clin Infect Dis, 68(6): 895-902.

8. SASINKA M, HRUSOVSKY S (2009) INFLUENZA A, Medical Horizon, 5 http:// www.cdc.gov/flu/professionals/diagnosis/rapidlab.htm.
9. CHEN L, TIAN Y, CHEN S, LIESENFELD O (2015) Performance of the Cobas( $\left({ }^{\circledR}\right)$ Influenza A/B Assay for Rapid Pcr-Based Detection of Influenza Compared to Prodesse ProFlu+ and Viral Culture. Eur J Microbiological Immunology (Bp), 5(4): 236-245. https://www.who.int/news-room/detail/1103-2019-who-launches-new-global-influenza-strategy. 